\title{
MASYARAKAT PRIBUMI PADA MASA PENJAJAHAN BELANDA DALAM NOVEL KISAH TANAH JAWA KARYA MADA ZIDAN DAN BONAVENTURA DE GENTA
}

\author{
Inladers in the Netherlands Kolonialism of the Novel Kisah Tanah Jawa by Mada \\ Zidan and Bonaventura De Genta
}

\author{
Ferdian Achsani \\ SMP N 1 Weru, Jalan Kapten Pattimura No.3, Desa Purung, Karangmojo \\ Kecamatan Weru, Kabupaten Sukoharjo \\ pos-el: dwikurniawan219@gmail.com
}

(Masuk: 27 September 2019, diterima: 09 April 2020)

\begin{abstract}
Abstrak
Novel Kisah Tanah Jawa bukan hanya novel yang mengandung unsur mistik semata. Dalam novel ini pembaca dapat menemukan gambaran kehidupan masyarakat pribumi selama masa kolonial Belanda. Keberadaan novel ini menjadikan pembelajaran baru bagi pembaca tentang sejarah masa kolonial Belanda. Penelitian ini bertujuan untuk mendeskripsikan bentuk kehidupan masyarakat pribumi selama masa kolonial Belanda yang terkandung dalam novel Kisah Tanah Jawa. Penelitian ini termasuk penelitian deskriptif kualitatif. Pendekatan yang digunakan dalam penelitian ini adalah strukturalisme genetik. Pengumpulan data menggunakan teknik baca dan catat. Uji validitas data dalam penelitian ini adalah triangulasi sumber. Data pada Penelitian ini dibandingkan dengan sumber dokumen teks lainnya. Hasil penelitian menunjukkan bahwa kehidupan masyarakat pribumi yang terjadi selama masa kolonial Belanda mengalami penderitaan seperti perempuan yang dijadikan gundik atau pelancur dan dijadikan tumbal, masyarakat pribumi dipaksa untuk kerja rodi dalam sistem pekerjaan atau mata pencaharian yang dibuat oleh Belanda dan berdampak pada ekonom pribumi yang lemah serta penindasan Belanda yang memandang derajat pribumi lebih rendah agar kekuasannya untuk menduduki tanah bumiputra tetap bertahan.

Kata kunci: strukturalisme genetik, sejarah, novel
\end{abstract}

\begin{abstract}
Javanese land story novels are not only novels that contain mystical elements. In this novel the reader can find a picture of the life of indigenous people during the Dutch colonial period, not just mystical stories. The existence of this novel makes a new learning for readers about the history of the Dutch colonial period. This study aims to describe the form of humanity facts of indigenous people during the Dutch colonial period contained in the novel Kisah Tanah Jawa. This research was included in a qualitative descriptive study. The approach used in this research is genetik structuralism. Data collection techniques used in this study are using reading and note taking techniques. Data validity test in this research is by triangulation of sources. The results of the study showed that the forms of life of indigenous people that occurred during the Dutch colonial period were like women who were made concubines or victims and made victims, indigenous people were forced to work hard in the occupational or livelihood systems created by the Dutch and impacted on the weak indigenous economists and Dutch oppression which views the indigenous ranks as lower so that its power to occupy the land of the native land remains.
\end{abstract}

Keywords: genetic structuralism, history, novels 


\section{PENDAHULUAN}

Kemampuan melihat hal-hal yang tak kasat mata merupakan keistimewaan yang tidak dimiliki oleh setiap orang. Bagi orang-orang yang memiliki keistimewaan tersebut mungkin dapat dijadikan sebagai pundi-pundi penghasilan. Hal itu terlihat dari adanya novel Kisah Tanah Jawa. Terbit pertama pada Desember 2018, novel ini sudah dicetak sampai empat kali pada Maret 2019. Kesuksesan novel Kisah Tanah Jawa dilatarbelakangi karena masyarakat saat ini seakan penasaran terhadap hal-hal gaib ataupun yang tidak kasat mata sehingga mereka merasa bahwa kehadiran buku ini dapat menjadi pengobat atau jawaban atas rasa penasarannya. Buku yang ditulis oleh tim Kisah Tanah Jawa ini berdasarkan dari kemampuan Hari Hao (Om Hao) yang dapat melihat dan berkomunikasi secara langsung dengan makhluk astral serta memiliki kemampuan retrokognisi, Mada Zidan yang cinta dengan sejarah dan Genta yang mentranskipkannya ke dalam karya tulis.

Berawal dari akun channel YouTube yang mencapai subscribe lebih dari 177.000 netizen, yang biasa menggunggah konten video dengan berbagai tema ini, Mada Zidan dan Bonaventura D. Genta merambah kesuksesannya dalam bercerita tentang hal-hal gaib ke dalam bentuk karya sastra novel. Meskipun dapat dikatakan bahwa Mada Zidan dan Bonaventura D. Genta ingin mengikuti jejak karier Risa Saraswati yang juga memiliki kemampuan dan karya yang sama, namun perbedaan tampak jelas dalam karya mereka. Novel-novel Risa Saraswati pada umumnya lebih bercerita tentang sahabatsahabat hantu yang dekat dengannya, sedangkan pada Kisah Tanah Jawa ini lebih mengeksplor sejarah-sejarah ataupun hal-hal mistis khususnya di tanah Jawa sendiri.

Novel Kisah Tanah Jawa karya Mada Zidan dan Bonaventura D. Genta ini memang berbeda dari novel-novel yang lainnya. Dalam novel ini, cerita lebih difokuskan pada ceritacerita mistis dan mitos yang berkembang di masyarakat seperti tempat-tempat angker maupun sosok-sosok yang selalu menjadi bahan hangat perbincangan masyarakat, khususnya di tanah Jawa. Cerita-cerita yang diambil dalam novel ini pun tidak luput dari tragedi yang pernah dialami oleh masyarakat pada umumnya. Tidak hanya seputar dunia mistis yang ditampilkan dalam novel ini, namun sejarah tanah Jawa seperti pada masa kolonial juga diceritakan dalam novel ini. Novel ini berisi pengalaman kelam yang pernah terjadi khususnya di tanah Jawa.

Selain bercerita tentang kisah-kisah mistis ataupun mitos yang terjadi di Tanah Jawa, novel ini juga bercerita tentang filisofi kebudayaan Jawa. Hal tersebut disampaikan oleh Zidan (2019) bahwa kehadiran buku ini merupakan kisah sejarah dengan balutan mistis yang bertujuan untuk memancing anak muda agar tidak melupakan leluhur atau nenek moyang dengan sejarah masa lalu. Mada menambahkan bahwa bukan hanya berisi kisah-kisah mistis dan misteri di pulau Jawa, tetapi melalui konten video dan novel tersebut ia ingin menyebarluaskan sejarah kepada masyarakat, terutama bagi generasi millenial yang saat ini mulai melupakan sejarah (Purwandono, 2019). Dari adanya novel Kisah Tanah Jawa ini, penyebaran sejarah dan budaya kepada masyarakat lebih mudah diterima oleh masyarakat. Pasalnya novel tidak hanya berisi dunia imajinasi, namun di dalamnya juga terdapat fakta yang dibuat oleh pengarang.

Karya sastra fiksi, baik itu novel, puisi, drama ataupun yang lainnya merupakan dunia imajinatif yang dibangun oleh pengarang dengan memanfaatkan media bahasa sebagai perantaranya. Dengan menggunakan bahasa yang indah, pengarang menuliskan kisah hidup, baik yang pernah dialaminya ataupun baik dari imajinasinya yang mampu menguggah suasana hati pembaca. Kadang-kandang, pengarang juga melukiskan gambaran kehidupan yang pernah dialami oleh orang lain. Ungkapan perasaan yang dituangkan oleh penyair merupakan bentuk ungkapan, baik yang terjadi di masa kini, masa lampau, ataupun masa yang akan datang. Sebagai dunia penuh kata, karya sastra tidak hanya sekadar ungkapan perasaan 
pribadi penyair, akan tetapi di dalamnya juga terdapat sejarah yang dapat dijadikan sebagai sarana untuk menyebarluaskan budaya. Sebagai suatu karya yang bersumber dari pengalaman yang pernah terjadi (nyata), maka karya sastra menjadi sebuah dokumen sejarah yang menjadi aset berharga dalam kehidupan masyarakat.

Karya sastra novel sebagai pengungkapan sejarah memang menjadi salah satu bahan alternatif yang dapat dilakukan. Hal itu juga disampaiakan oleh Endawarsana (2012: 1) bahwa novel merupakan lukisan sosial dan sejarah. Dengan adanya karya sastra yang bermuatan sejarah, pembaca tidak hanya mendapatkan keindahan cerita, namun juga dapat belajar sejarah darinya. Misalnya saja karya sastra novel dapat digunakan untuk mengungkapan bentuk-bentuk praktik kolonial. Hafid (2017) pernah melakukan penelitian yang mengkaji tentang bentuk-bentuk diskriminasi yang terdapat pada novel Salah Asuhan Karya Abdoel Moeis. Dari hasil penelitiannya tersebut, Hafid menjelaskan bahwa bentuk-bentuk diskriminasi yang dilakukan oleh bangsa Belanda terhadap pribumi seperti diskriminasi dalam bentuk ras, gender, adat-istiadat, maupun budaya. Bangsa Belanda menanamkan idiologi bahwa bangsa Belanda adalah bangsa yang bermartabat dan lebih tinggi dari bangsa Indonesia. Dari penelitian tersebut, dapat diketahui bahwa karya sastra novel merupakan bentuk penggambaran sejarah dari suatu masa. Meskipun pengarang sering menambahi ceritacerita di luar konteks yang sebenarnya, namun latar belakang budaya yang diambil dapat dari novel dapat dijadikan bahan pembelajaran. Hal tersebut juga tidak lepas dari peran angkatan karya sastra dari setiap karya sastra yang memiliki ciri khas masing-masing.

Sejarah merupakan salah satu aset berharga dari suatu bangsa. Sejarah merupakan catatan berbagai peristiwa yang pernah terjadi di suatu masa. Melalui sejarah, diharapkan dapat dijadikan sebagai pengajaran bagi masyarakat agar lebih baik untuk masa-masa yang akan datang. Misalnya saja kita pernah membaca tafsir dari kitab suci Alquran yang salah satunya berisi kisah-kisah sejarah, baik dari para nabi maupun para malaikat. Dari kisah-kisah tersebut, Alquran mengajarkan kepada umat Islam untuk belajar agar dapat dijadikan teladan dalam menjalani kehidupan di bumi ini. Amin (2010: 13) mengungkapkan bahwa belajar sejarah merupakan salah satu kewajiban karena di dalamnya mengandung nilai-nilai dan kekuatan untuk membangun perkembangan peradaban kehidupan yang lebih baik, dari masa lalu atau kejadian yang pernah terjadi.

Pembelajaran sejarah melalui karya sastra merupakan salah satu hal yang unik dan menarik, meskipun menuai banyak perdebatan. Adanya fiksi dan fakta pada suatu karya sastralah yang menimbulkan perdebatan itu. Terlepas dari itu semua, Ratna (2013: 108) mengungkapkan bahwa suatu karya sastra merepresentasikan keadaan suatu masyarakat pada suatu masa. Pengarang menangkap fenomena kemasyarakatan tersebut dan menuliskannya ke dalam bentuk karya sastra sehingga suatu karya sastra dapat digunakan sebagai pembelajaran sejarah untuk mengetahui gambaran keadaan masyarakat di suatu masa. Karya sastra mencoba memberikan pemaknaan atau interpretasi terhadap kejadian atau peristiwa yang sudah terjadi (Mahayana, 2014: 3).

Suaka (2013: 83) mengungkapkan bahwa analisis historis pada karya sastra mengandung artian bahwa karya sastra merupakan fakta sejarah karena karya sastra mewakili peradaban semangat pada zamannya. Pendekatan strukturalisme genetik dapat digunakan untuk mengetahui bahwa dalam karya sastra tersebut memiliki hubungan dengan sejarah kehidupan masyarakat. Strukturalisme genetik merupakan salah satu pendekatan karya sastra di bawah payung sosiologi sastra. Kemunculan strukturalisme genetik ini didasari oleh sikap protes dari pendekatan strukturalisme yang hanya mengkaji unsur intrinsik atau unsur pembangun dalam suatu karya sastra, tanpa melibatkan unsur luar 
(esktrinsik) dalam karya sastra. Padahal, unsur ekstrinsik dalam suatu karya sastra juga menjadi dasar untuk membangun suatu karya sastra. Untuk itu, strukturalisme genetik hadir menjadi jembatan penghubung antara strukturalisme (unsur intrinsik) dengan sosiologi (unsur ekstrinsik).

Strukturalisme genetik merupakan pendekatan yang paling cocok untuk memahami bagaimana pola kehidupan masyarakat. Sebagaimana penelitian yang dilakukan oleh Basid, Nur, \& Zuhdy (2018: 99), yang mengungkapkan pola kehidupan masyarakat Pontianak dengan menggunakan pendekatan strukturalisme genetik. Hal ini menjadi dasar bahwa strukturalisme genetik dapat digunakan untuk mengungkapkan keadaan suatu masyarakat.

Ridwan, Aries, \& Yulianeta (2016: 67) menyatakan bahwa strukturalisme genetik berpijak pada pandangan bahwa karya sastra adalah sebuah struktur yang bersifat dinamis karena merupakan produk sejarah dan budaya yang berlangsung secara terus menerus. Adanya fakta kemanusiaan yang terdapat pada suatu karya sastra menjadikan karya sastra tersebut dapat dikaji dari segi strukturalisme genetik. Fakta kemanusiaan merupakan segala aktivitas yang berhubungan dengan kehidupan manusia, baik yang dialami secara pribadi maupun yang dialami secara sosial masyarakat. Pendekatan strukturalisme genetik ini diharapkan dapat menjabarkan bagaimana kehidupan masyarakat pribumi yang tercermin dalam novel Kisah Tanah Jawa pada masa penjajahan kolonial Belanda.

Sebagai negara yang pernah dijajah oleh negara-negara kolonial seperti Portugis, Inggris, Belanda, dan Jepang, maka meninggalkan bekas-bekas yang sampai sekarang masih dirasakan oleh masyarakat. Salah satu bekas yang dapat ditemukan adalah bukti-bukti bagaimana kisah hidup yang pernah alami oleh masyarakat pribumi, yang disebabkan oleh kedudukan bangsa-bangsa kolonial tersebut yang berkuasa di Negara Indonesia. Dokumen novel Kisah Tanah Jawa, dapat dijadikan pelengkap dari adanya proses-proses atau bentuk kehidupan masyarakat, salah satunya yaitu menurut Audriana (2018: 2), berakibat pada ketidakadilan dan pemiskinan yang pernah dilakukan oleh bangsa-bangsa kolonial tersebut kepada bangsa Indonesia. Dengan demikian, adanya karya sastra ini dapat dijadikan sebagai dokumen pelengkap untuk mempelajari sejarah.

Penelitian terkait penggambaran novel sejarah dan yang relevan dengan penelitian yang akan dilakukan ini pernah dilakukan oleh Saputra \& Etmi (2018) dengan membandingkan novel Jugun Ianfu: Jangan Panggil Aku Miyako karya Enang Rokajat Asura dan novel Cantik Itu Luka karya Eka Kurniawan. Hasil penelitian tersebut menyatakan bahwa perempuan Hindia Belanda pada masa penjajahan Jepang dijadikan sebagai pemuas nafsu para serdadu Jepang. Awalnya mereka diiming-imingi akan disekolahkan, namun ternyata hal tersebut hanyalah tipu muslihat belaka. Sebagai pemuas nafsu, perempuan pribumi disiksa apabila mereka menolak untuk melayani hasrat para serdadu. Persamaan penelitian ini dengan penelitian tersebut adalah menggambarkan keadaan masyarakat pada masa penjajahan, yang terdapat pada karya sastra novel. Perbedaan penelitian terletak pada objek yang dikaji. Pada penelitian Saputra \& Etmi menggunakan dua novel, yaitu novel Jugun Ianfu: Jangan Panggil Aku Miyako karya Enang Rokajat Asura dan novel Cantik Itu Luka karya Eka Kurniawan. Penelitian ini akan menggunakan novel Kisah Tanah Jawa sebagai objek penelitian.

Penelitian yang dilakukan oleh Wicaksono (2016) mengkaji novel-novel karya Andrea Hirata dengan pendekatan strukturalisme genetik juga relevan dengan penelitian ini. Hasil penelitian tersebut menyimpulkan bahwa keramahan masyarakat Melayu dalam novelnovel karya Andrea Hirata ditunjukkan dengan sikap saling gotong royong dan toleransi tanpa memandang ras, suku dan budaya. Hal ini tercermin dari kerukunan hidup bermasyarakat 
yang digambarkan dalam setiap novel-novel karya Andrea Hirata. Persamaan penelitian ini dengan penelitian tersebut adalah kajian atau pendekatan yang digunakan untuk mengkaji sebuah novel, yaitu pendekatan strukturalisme genetik dan sama-sama mengkaji gambaran kehidupan masyarakat. Perbedaan terletak pada objek yang digunakan. Pada penelitian sebelumnya, Wicaksono mengkaji novel-novel Karya Andrea Hirata untuk melihat kearifan lingkungan hidup masyarakat Melayu, sedangkan pada penelitian ini menggunakan novel Kisah Tanah Jawa untuk melihat keadaan masyarakat pribumi pada masa penjajahan kolonial Belanda.

\section{METODE}

Penelitian ini termasuk penelitian deskriptif kualitatif, dengan pendekatan strukturalisme genetik. Deskriptifkualitatif merupakan bentuk penelitian yang mendeskripsikan atau memaparkan hasil temuan data dalam bentuk tulisan sesuai apa yang ditemukan. Penelitian ini memaparkan bentuk fakta kemanusiaan dari kehidupan masyarakat pribumi (bangsa Indonesia) pada masa kolonial Belanda. Proses pengumpulan data dilakukan dengan cara teknik baca, yaitu membaca keseluruhan isi naskah novel kemudian menggabungkannya dengan teknik catat. Peneliti mencatat atau menandai kutipan-kutipan yang dijadikan sebagai data pada penelitian ini.

\section{HASIL DAN PEMBAHASAN}

Awal kedatangan bangsa Belanda yang pertama yaitu ingin menguasai rempah-rempah yang ada di Nusantara. Namun akhirnya mereka melakukan penindasan terhadap pribumi, salah satunya yaitu pada aspek perdagangan yang menjadi pekerjaan atau sistem mata pencaharian bagi masyarakat pribumi. Akibatnya, ekonomi masyarakat pribumi kian hari kian melemah. Kedatangan bangsa Belanda yang awalnya ingin mencari rempah-rempah di tanah bumiputra, pada akhirnya menuntun mereka untuk merampas dan menguasai seluruh daerah-daerah yang menjadi pusat penghasil rempah-rempah. Salah satu usaha atau taktik yang dilakukan oleh Belanda adalah dengan mendirikan serikat dagang bernama VOC. VOC merupakan salah satu serikat dagang yang dibentuk oleh Belanda untuk memonopoli perdagangan di Nusantara. Atas kepercayaan Belanda yang memberikan kekusaan atau hak istimewa pada VOC tersebut, VOC membentuk sistem pemerintahan tersendiriyang kemudian terkenal dengan istilah negara dalam negara.

Kedatangan VOC adalah untuk memonopoli perdagangan rempahrempah di Nusantara. Berbagai macam cara dilakukan untuk mempertahankannya. Antara lain mengintimidasi penduduk di pulau-pulau penghasil rempah (Zidan \& Bonaventura, 2019: 124).

VOC didirikan pada 20 Maret 1602, bertujuan untuk memonopoli perdagangan di nusantara dan ingin menyaingi perdagangan EIC yang telah dibentuk oleh Inggris. VOC atau kompeni berkantor pusat di Banten. Kutipan di atas menjelaskan bahwa banyak cara yang dilakukan oleh VOC untuk memonopoli perdagangan rempah-rempah di nusantara, salah satunya dengan melakukan intimidasi terhadap kaum pribumi. Bentuk intimidasi yang dilakukan oleh VOC tersebut dilatarbelakangi adanya beberapa peraturan yang dibuat oleh VOC, misalnya VOC memaksa pribumi untuk menjual hasil rempah-rempah seperti lada, kapas, gula, kayu, hanya kepada VOC, kemudian rakyat juga diwajibk untuk membayar pajak tanah atau hasil bumi kepada VOC. Kedua peraturan tersebut merupakan bentuk intimidasi yang dilakukan oleh VOC untuk memonopoli perdagangan di nusantara.

Intimidasi yang dilakukan oleh VOC terhadap perdagangan pada masyarakat pribumi tersebut sempat mengalami puncak keemasan atau kejayaan di seratus tahun pertama. Tiga tahun pertama didirikannya VOC, Belanda telah berhasil menguasai kepulauan Maluku yaitu tepatnya pada tahun 
1605 dan kemudian terus berkembang mengalami masa puncak keemasan tersebut (Djakariyah, 2014: 76). VOC berhasil menguasai dan merebut Maluku setelah berhasil merebut benteng pertahanan Portugis karena hal tersebut merupakan tugas tambahan VOC untuk menghancurkan Portugis di Asia, selain memonopoli perdagangan di bumiputra. VOC dibubarkan pada 31 Desember 1799. Hal ini disebabkan karena banyak pegawai yang korupsi dari hasil perdagangan yang dilakukan oleh VOC. Pengeluaran VOC yang makin besar akibat melakukan perang, salah satunya dengan kerajaan-kerajaan Jawa yang memberontak seperti kerajaan Mataram, Banten, Makasar, dan Maluku, menyebabkan kas VOC semakin menyusut. Akhirnya VOC dinyatakan bangkrut dan akhirnya dibubarkan, kemudian kekuasaan VOC diambil alih oleh pemerintah kolonial Belanda.

Dari uraian tersebut dapat dipahami bahwa kekejaman yang dilakukan oleh VOC untuk memonopoli rempah-rempah di Nusantara, mengakibatkan banyak pribumi semakin menderita. Akibatnya masyarakat pribumi semakin terdesak dan kedudukannya semakin diinjak-injak. Sistem kerja paksa yang dilakukan oleh bangsa Belanda baik dari pertanian dan perdagangan yang menjadi sumber penghasilan utama masyarakat membuat kaum pribumi banyak yang mengalami kesengsaraan pada aspek pekerjaan yang berdampak pada ekonomi masyarakat.

Mereka mencari keuntungan dengan membuat lingkaran setan. Ibaratnya memberi pekerjaan dan digaji, tapi gajinya digunakan untuk membeli opium atau candu sehingga pihak Belanda mendapatkan keuntungan yang berlipat dan rakyat semakin dibuat menderita (Zidan \& Bonaventura, 2019: 138).

Bentuk intimidasi perdagangan juga tergambar pada kutipan di atas. Dalam kutipan tersebut diceritakan bahwa masyarakat pribumi yang tidak memiliki tanah, mereka diwajibkan untuk membantu perkebunan atau pertanian oleh Belanda. Hasil kerja mereka tidak sepenuhnya diberikan langsung. Dalam artian gaji yang telah diberikan oleh Belanda kepada para pekerja wajib digunakan untuk membeli candu. Candu menjadi penyakit yang mengakibatkan pribumi tertipu dan saling membunuh. Hal tersebut semakin membuat masyarakat pribumi semakin menderita akibat monopoli perdagangan Belanda oleh candu.

Selain tanam paksa, Pada masa penjajahannya Belanda juga menerapkan sistem kerja paksa yang menjadikan kesengsaraan bagi masyarakat pribumi. Pada masa tersebut banyak pribumi yang mati kelaparan atau karena kelelahan, karena tidak digaji atau hanya digaji sedikit, akibat dari sistem kerja rodi yang diberlakukan oleh Belanda. Kekejaman penjajah menjadikan masyarakat tidak memiliki pilihan, kecuali harus mengikuti seluruh aturan dan menjalankannya meskipun sangat berat (Krismawati, 2013: 25). Setelah VOC resmi dibubarkan, kini pemerintah kolonial Belanda menduduki pemerintahan di Nusantara. Tidak jauh berbeda dengan VOC, pemerintah kolonial Belanda juga menerapkan sistem kerja rodi. Salah satu bentuk kerja rodi yang pernah dilakukan yaitu pembuatan jalur rel kereta api. Kolonel JHR Van Der Wijk merupakan tokoh pemrakarsa pembuatan rel kereta api di Indonesia. Hal ini didasari karena kurangnya angkutan transportasi untuk mengangkut hasil bumi ke Batavia. Akhirnya Kolonel JHR Van Der Wijk mengajukan proposal untuk membuat jalur rel kereta api agar pengangkutan hasil bumi bisa berjalan dengan lancar dan bisa tiba di tempat sesuai dengan waktunya. Meskipun mendapat persetujuan dari pihak Belanda, tetapi pembangunan rel kereta api tidak langsung dilaksanakan. Butuh 23 (dua puluh tiga) tahun setelah pengajuan itu diajukan, barulah pembangunan rel kereta api di Indonesia dilakukan. Salah satu perusahaan stasiun kereta api yang didirikan oleh pemerintah kolonial Belanda adalah Staatsspoorwegen (ss). Pada tahun 1914-1915, perusahaan kereta api Staatsspoorwegen membangun jalur kereta api 
Cirebon-Kroya. Dalam pembangunan jalur kereta api ini dilakukan dengan sistem kerja paksa. Hal itu menyebabkan pribumi banyak yang sakit dan letih sehingga banyak dari mereka yang kehilangan nyawa.

Pembangunana jalur ini cukup banyak menelan korban jiwa sebab dijalankan dengan sistem kerja paksa. Hal tersebut dibuktikan dengan terdapatnya makam tua di bukit di atas perlintasan kereta api di daerah Notog, yang merupakan makam dari pekerja paksa (Zidan \& Bonaventura, 2019: 6).

Kutipan di atas menjelaskan bentuk kerja paksa yang dilakukan oleh pemerintah kolonial Belanda terhadap masyarakat pribumi dalam pembangunan rel kereta api. Dalam kutipan di atas digambarkan bahwa pembangunan rel kereta api yang dilakukan oleh statiun swasta Ss untuk menghubungkan daerah CirebonKroya itu memakan banyak korban. Kerja paksa dalam pembangunan jalur kereta api merupakan salah satu bentuk penindasan yang dilakukan oleh pemerintah Belanda terhadap masyarakat pribumi. Adanya sistem kerja paksa ini membuat masyarakat pribumi semakin sengsara hingga menelan banyak korban. Rakyat tidak kuat karena harus menghadapi perlakuan sistem kerja paksa, sehingga menyebabkan mereka banyak yang kehilangan nyawa. Mereka dimakamkan di bukit di atas perlintasan kereta yang menjadi tempat peristirahatan para korban dari pekerja paksa sekaligus sebagai saksi kekejaman Belanda terhadap pribumi.

Estimasi kami, ada 100 ribuan nyawa melayang, terutama diakibatkan oleh penyakit malaria serta perlakuan kejam Daendels beserta tentaranya yang asal tebas kepala ketika para pekerja paksa tampak letih dan mulai sakit-sakitan (Zidan \& Bonaventura, 2019: 130).

Selain pembangunan rel kereta api, salah satu pembangunan jalan yang menghubungkan antara Anyer - Panarukan juga terkenal dengan pengorbanan ribuan nyawa. Jalan pantai utara (pantura) sudah tidak asing lagi bagi masyarakat Indonesia. jalur ini merupakan salah satu jalur yang menjadi saksi atas penindasan bangsa penjajah terhadap masyarakat bumiputera. Jalur yang menghubungkan antara kawasan Jawa Tengah dan Jawa Timur ini menjadi jalur terpanjang di dunia, dengan panjang 1000 kilometer. Jalur ini dulunya dikenal dengan nama Grote Postweg (Jalan Raya Pos) bahkan popular dengan nama Jalan Daendels, sesuai dengan nama pemimpin gubernur yang memprakasai pembuatan jalur tersebut.

Kutipan di atas menceritakan kekejaman kerja paksa yang diberlakukan Daendels terhadap masyarakat pribumi. Sistem kerja paksa yang digagasnya dalam pembuatan jalur ini demi kepentingan pemerintahan Belanda di tanah jajahan menyebabkan kesengsaran bagi pribumi. Banyak dari masyarakat pribumi yang kehilangan nyawa dalam pembuatan jalur ini akibat kelelahan ataupun tekena tebasan. Selain itu adanya wabah penyakit malaria yang kala itu menjadi momok bagi masyarakat pribumi juga menjadi penyebab masyarakat pribumi kehilangan nyawa.

Dari kutipan di atas dapat dipahami bahwa pada masa kolonial Belanda, kedudukan kaum pribumi sangat sengsara karena adanya sistem kerja paksa. Sebagai bangsa "terjajah", Indonesia diperlakukan seperti budak di negeri sendiri, yaitu penjajah memperlakukan Bangsa Indonesia dengan sistem kerja rodi, diperas tenaga dan harga diri bangsa Indonesia hanya untuk membesarkan sang penjajah (Yurnal, 2016: 6).

Selain suka bertindak semena-mena pada masyarakat biasa, Gubernur Jendral Daendels juga tak segan-segan merendahkan strata sosial para raja. Strata sosial menjadi salah satu hal yang harus direbut oleh para menner Belanda untuk tetap bertahan dan mempertahankan kedudukannya di tanah jajahan. Tujuannya, agar pemerintahan kolonial Belanda tetap berkuasa dan masyarakat pribumi mau menuruti setiap perintahnya. Untuk tetap 
mempertahankan kedudukannya tersebut, maka pemerintahan Belanda melakukan penindasan terhadap para raja pribumi. Belanda menganggap bahwa derajat mereka lebih tinggi daripada kaum pribumi. Salah satunya ditunjukkan oleh Daendels yang melakukan perbuatan tidak baik ketika ia berjabat tangan dengan raja Jawa.

Daendels tidak takut bahkan cenderung merendahkan bangsawan Jawa. Dia suka membalas jabatan tangan dengan tangan kiri (Zidan \& Bonaventura, 2019: 132).

Kutipan di atas menceritakan bahwa Daendels merupakan gubernur jenderal kolonial Belanda yang tidak hanya kejam tetapi juga sombong. Dalam kekuasannya Daendels banyak menentang peraturan-peraturan yang dibuat oleh para raja-raja di Jawa. Salah satu peranturan yang dilanggar oleh Daendels misalnya saja ketika bertemu dengan raja, Daendels tidak ingin melepas topi. Selain itu, Daendels juga ingin duduk di kursi yang derajatnya sama dengan raja. Kutipan tersebut juga menggambarkann bahwa Daendels tidak memiliki rasa menghargai terhadap raja-raja di tanah Jawa. Kutipan tersebut menggambarkan bahwa tak tanggung-tanggung, Daendels suka membalas jabatan tangan kanan para raja dengan tangan kiri. Hal ini menandakan bahwa dalam bentuk status sosial pun para pribumi juga mengalami penindasan secara tidak terhormat. Sebagai seorang pemimpin yang seharusnya dihormati oleh rakyat, ia justru diperlakukan rendah atau bahkan hina oleh sikap angkuh Daendels. Kutipan tersebut sama dengan yang disampaikan oleh (Daliman, 2012: 18) bahwa Daendels tidak menunjukkan sikap hormatnya kepada raja-raja. Daendels sering bertindak tegas dengan menggunakan taktik kekerasan.

Adanya bentuk-bentuk penindasan yang dilakukan oleh pemerintah kolonial Belanda, memunculkan semangat dari para masyarakat pribumi untuk memberontak dan melawan penjajah. Salah satunya yaitu ditunjukkan dengan adanya perang Jawa. Perang Jawa merupakan salah satu perang terbesar yang pernah terjadi di Indonesia. Pangeran Diponegoro, merupakan salah satu pemimpin dari perang ini. Perang ini dipelopori karena keinginan masyarakat untuk mengusir kebiadaban para penjajah.

Perang Diponegoro menjadi salah satu bukti adanya bentuk perlawanan yang dilakukan oleh masyarakat pribumi karena ingin menentang kebijakan Belanda yang semenamena terhadap masyarakat pribumi. Sistem tanam paksa yang digagas oleh pemerintah Belanda setelah berakhirnya masa VOC menjadikan masyarakat semakin tertindas sehingga mereka bersatu melawan para penjajah ataupun para pribumi yang berkhianat.

Berakhirnya perang Jawa pada tahun 1830 yang ditandai dengan ditangkapnya Pangeran Diponegoro dengan tipu daya licik Belanda, membuat banyak pengikut setia Diponegoro yang kemudian melarikan diri agar tidak turut tertangkap. Mereka menyamarkan nama asli agar keberadaannya tidak diketahui oleh pihak Belanda, mengingat saat itu tidak sedikit pribumi yang menjual informasi kepada pihak penjajah karena mengharapkan imbalan (Zidan \& Bonaventura, 2019: 68).

Perang Diponegoro merupakan salah satu perang terbesar yang pernah trejadi di tanah Jawa. Perang ini merupakan perang terbesar di tanah Jawa yang bertujuan untuk mengusir pejajah dan menegakkan keadilan. Perang ini dipicu oleh berbagai sebab, salah satunya yaitu adanya pembayaran berbagai macam pajak yang membebani rakyat. Adanya berbagai macam pajak dan sistem kerja paksa yang diberlakukan oleh pemerintahan Belanda ini pun membuat rakyat semakin sengsara dan menderita. Akhirnya, Pangeran Diponegoro bersama rakyat dan dibantu dengan para bangsawan pun melakukan penyerangan yang dikenal dengan Perang Jawa. Perang yang Beliau pimpin berlangsung selama lima tahun ini diakhiri dengan adanya perjanjian yang akhirnya berunjung dengan penculikan. Belanda 
menggunakan taktik licik untuk menjebak Pangeran Diponegoro, yaitu dengan dalih mengajak Pangeran Diponegoro untuk berunding.

Secara diam-diam Belanda mempersiapkan jebakan untuk menangkap Diponegoro. Setelah dilakukannya perjanjian tersebut, Pangeran Diponegoro kemudian diculik dan diasingkan ke Manado selama 25 tahun hingga Beliau wafat (Kartodirjo, 2014: 446). Berakhirnya perang Diponegoro yang menewaskan setidaknya 200.000 orang dan mencapai kerugian sekitar 2 gulden tersebut juga menandakan bahwa kondisi ekonomi pemerintah Belanda mengalami kerugian besar. Sebagai akibat dari perang tersebut, masyarakat bagian selatan harus membayar ganti rugi dengan melakukan tanam paksa selama 40 tahun.

Sistem kerja paksa dan berbagai pembayaran pajak yang harus ditanggung masyarakat tersebut otomatis berdampak pada ekonomi masyarakat. Hal ini terlihat dari kutipan di atas, bahwa mayarakat pribumi banyak yang menjual informasi kepada pihak Belanda agar mereka mendapatkan imbalan. Dengan imbalan yang didapatkannya tersebut mereka berharap bisa mendapat jaminan dan dapat digunakan untuk mempertahankan hidup. Seharusnya, mereka saling menyembunyikan informasi agar saling menjaga saudara seperjuangan melawan penjajah. Namun karena diiming-imingi imbalan yang dapat digunakan untuk kelangsungan hidup, merekapun tak tanggung-tanggung mengorbankan saudara sendiri. Untuk melindungi diri, maka para pejuang perang yang masih hidup menyembunyikan identitas diri mereka agar tidak diketahui oleh pihak Belanda.

Kesengsaraan akibat perbudakan yang dilakukan oleh pemerintah kolonial Belanda berdampak pada pola pikir masyarakat yang memilih menggunakan cara-cara instan untuk mendapatkan kesejahteraan hidup. Mereka yang kurang akan pemahaman agama dan tergiur dengan nafsu setan membuatnya melakukan cara-cara kotor.

Dan yang lebih mengerikan lagi adalah ketika proses pemberian tumbal bayi pada tiang pancang utama. Awalnya pihak penanggung jawab proyek mendapat informasi ada salah satu buruh bangunan yang istrinya baru saja melahirkan. Kemudian, pihak penanggung jawab mendekati keluarga si buruh bangunan untuk menyerahkan bayi mereka dengan iming-iming uang yang nilainya cukup banyak (ratusan juta), dengan dalih akan diadopsi (Zidan \& Bonaventura, 2019).

Keadaan ekonomi yang sangat mengkhawatirkan membuat pribumi terpaksa mengorbankan berbagai hal untuk mendapatkan kesejahteraan. Seperti yang tampak pada kutipan di atas bahwa orang tua tega menjual anaknya agar bisa mendapatkan uang untuk kelangsungan hidup. Dengan dalih akan diadopsi, maka sang orang tua pun tak segan-segan memberikan bayi mereka kepada penanggung jawab proyek. Namun ternyata hal tersebut hanya tipuan yang dibuat oleh Belanda. Mereka sengaja membeli bayi karena akan digunakan sebagai tumbal dalam pembuatan jembatan agar proses pembangunan bisa berjalan dengan lancar dan selesai tepat waktu tanpa ada hambatan.

Selain menjual anak, dalam novel Kisah Tanah Jawa ini digambarkan bahwa lemahnya keadaan ekonomi yang dialami oleh bangsa pribumi, memaksa sebagian orang untuk mencari pesugihan (ritual ilmu sihir yang digunakan untuk mendapatkan kekayaan). Dengan cara bersekutu dengan setan, maka dipercayai bahwa segala yang diinginkan akan dapat terpenuhi. Mereka yang melakukannya akan mendapatkan kekayaan yang berlimpah tanpa harus susah payah banting tulang bahkan sampai memeras keringat untuk mengumpulkan uang. Namun yang harus dipahami bahwa bahwa bersekutu dengan setan bukanlah jalan utama untuk mencari kesejahteraan karena 
banyak resiko yang harus mereka tanggung, salah satunya mereka bisa kehilangan nyawa bahkan mendapat kesengsaraan di akhirat

Pada masa kolonial babi ngepet digunakan untuk mengambil bahan makanan seperti beras dan perhiasan emas. Sasarannya adalah tuan-tuan Belanda dan masyarakat golongan menengah ke atas (Zidan \& Bonaventura, 2019: 31).

Babi ngepet merupakan salah satu ilmu pesugihan yang sangat terkenal di Indonesia. Ritual ini dilakukan oleh dua orang, yang mereka adalah sepasang suami istri. Salah seorang akan menjadi babi, dan yang seorang lagi menjaga lilin sebagai simbol aman atas diri yang sedang mengepet. Pada kutipan di atas diceritakan bahwa kemiskinan yang dialami oleh masyarakat pribumi memaksa mereka untuk melakukan ritual haram tersebut. Ritual tersebut sangat familiar pada masa kolonial Belanda, karena digunakan oleh masyarakat pribumi untuk mengambil harta kekayaan dari masyarakat golongan menengah ke atas dan para menner Belanda. Jika sang suami telah berubah menjadi babi dan siap menuju rumah target yang dituju, maka istri berkewajiban menjaga lilin agar tetap menyala sebagai simbol bahwa suaminya tertap aman.

Baik ritual babi ngepet ataupun ajian-ajian lainnya dalam masyarakat, khususnya masyarakat Jawa memang sesuatu yang sudah familiar. Kelompok masyarakat yang sering melakukan hal seperti ini disebut sebagai abangan. Abangan merupakan istilah yang sering digunakan untuk menyebutkan orangorang yang mengaku meyakini syariat agama Islam, namun tidak pernah melaksanakan perintah-perintah agama seperti salat, puasa, zakat, haji, dan lain-lain. Ricklefs (2012: 112) menambahkan bahwa kaum abangan ini ketika pada waktu kematian dan kelahiran berharap agar ritul agama Islam dijalankan. Maka, orang-orang yang melakukan ritual seperti ritual babi ngepet ataupun ilmu pemikat dapat dikatakan sebagai bentuk penganut Islam abangan karena mereka menyekutukan Tuhan. Abdullah (2013: 24) menyatakan bahwa pada masa penjajahan, Islam abangan banyak yang berasal dari golongan priyayi atau para pegawai keraton. Namun juga tidak menutup kemungkinan bahwa golongan petani juga termasuk Islam abangan.

Tidak hanya pesugihan dan kaum pribumi yang menjual informasi kepada pihak Belanda. Penggunaan ilmu pelet dan jaran goyang juga digunakan oleh para perempuan pribumi sebagai upaya untuk mendapatkan kesejahteraan hidup. Ilmu semacam ini digunakan oleh para perempuan untuk menarik perhatian para menner Belanda. Mereka rela mengorbankan harga diri dan martabat mereka untuk bisa mendapatkan penghasilan dan kesejahteraan hidup. Karena perempuan Belanda di tanah Hindia Belanda (bumiputra) pada saat itu tidak terlalu banyak, maka para menner pun meluapkan nafsu mereka pada budak-budak perempuan yang bekerja sebagai pembantu di rumah mereka. Jika salah satu dari mereka beruntung, mereka akan mendapat sebutan nyai. Nyai menduduki posisi yang paling tinggi bagi perempuan pribumi yang menjadi simpanan para menner.

Perempuan pada masa kolonial penjajahan Belanda, kedudukannya sangat dipandang hina. Mouton \& Co S, (2017: 235) menulis bahwa keadaan mereka sangat terhambat untuk memperoleh pekerjaan yang layak. Banyak dari mereka yang hanya digunakan sebagai budak pemuas nafsu (perempuan jalang) atau sebagai babu (jongos). Bahkan mereka yang imannya rendah akan melakukan berbagai macam cara untuk menarik perhatian menner.

Penindasan terhadap perempuan merupakan permasalah yang dilakukan oleh Belanda pada masalah gender. Hal yang paling menonjol dari adanya penindasan ini adalah bahwa perempuan hanya dianggap sebagai seonggok daging yang siap untuk dijadikan korban setiap saat. Salah satu cerita yang terkenal misalnya adalah Nyai Saritem, yang kini nama tersebut sangat tersohor bagi 
masyarakat Jawa Barat. Sebelum mendapat gelar Nyai, Sarintem merupakan sosok gadis yang cantik belia. Kecantikannya mampu memikat pesona seorang menner Belanda hingga dia pun akhirnya dijadikan sebagai gundik. Setelah beberapa lama kemudian, pembesar Belanda meminta Sarintem untuk mencari perempuan yang dapat dijadikan teman kencan bagi serdadu Belanda yang masih lajang. Semakin hari bisnis lendir Sarintem kian ramai, bahkan tidak hanya para serdadu yang melajang, tetapi juga para prajurit yang lanjut usia atau para masyarakat pribumi pun juga tertarik untuk mencicipinya. Hingga saat ini tempat tersebut masih terkenal dengan nama Sarintem. Dari bisnis Sarintem tersebut sehingga dapat dipahami bahwa perempuan sangat tertindas karena ia tidak memiliki harga diri dan dianggap sebagai pemuas nafsu.

Dalam novel Kisah Tanah Jawa ini digambarkan bagaimana cara perempuan dalam merayu para menner Belanda, salah satunya yaitu dengan ilmu pelet.

Ilmu ini merebak ketika masa kolonial, terutama di daerah Jawa Barat. Para gundik atau perempuan simpanan meneer Belanda sengaja mencampurkan darah menstruasinya agar para menner turut dan menurut kepada sang gundik (Zidan \& Bonaventura, 2019: 80).

Kutipan di atas menceritakan bahwa para perempuan pada masa kolonial yang menggunakan ajian ilmu pelet, salah satunya yaitu menggunakan darah menstruasi. Dengan mencampurkan darah menstruasi pada makanan atau minuman yang dihidangkan kepada para menner, siapapun yang terkena pelet tersebut akan mudah tergoda oleh rayuan orang yang menggunakannya.

Peraturan adat dan peraturan dari Belanda yang membelenggu perempuan membuat para perempuan seakan-akan adalah makhluk yang lemah. Mereka hanya ditempatkan untuk mengurus rumah tangga seperti halnya menjadi babu atau jongos. Namun untuk pribumi yang bergemilang harta atau dapat dikatakan sebagai keturunan para bangsawan, mereka sangat diperlakukan istimewa. Agar kehidupannya tidak tertindas, para perempuan berusaha merebut hati menner Belanda demi mendapatkan uang merupakan salah satu cara yang dapat dilakukan agar mendapatkan kehidupan yang layak.

Keadaan yang demikian memang benarbenar terjadi. Bahkan di masa modern saat ini hal-hal mistis seperti itu pun terkadang masih sering dijumpai. Kepercayaan terhadap hal-hal yang gaib, sudah menjadi kebiasaan bagi masyarakat Indonesia. Maka tidak diherankan lagi apabila pribumi banyak yang menggunakan hal-hal semacam ini guna mendapatkan atau mewujudkan keinginannya. Perlakuan yang demikian dapat disebabkan karena kurangnya pemahaman ajaran agama yang dianut, karena memang pada masa kolonial Belanda pengajaran agama Islam sangat dilarang, sebab yang ditakutkan bahwa islam yang merupakan agama pembela akan menjadikan masyarakat pribumi bergerak untuk memberontak pemerintahan Belanda. Hal yang demikian menjadikan iman sebagian masyarakat pribumi mudah dibujuki setan, sehingga mereka melakukan cara-cara haram untuk mendapatkan kebahagiaan hidup.

Kembali lagi ke pembahasan Jaran Goyang tadi, ajian ini kemudian kembali berkembang di masa kolonial. Para perempuan pribumi banyak menggunakannya untuk menarik perhatian para menner Belanda atau juragan local dengan maksud mendapat kesejahteraan secara instan (Zidan \& Bonaventura, 2019: 83).

Selain menggunakan ajian ilmu pelet dengan menggunakan darah menstruasi untuk memikat hati para menner Belanda, para perempuan pribumi juga menggunakan ajian ilmu jaran goyang demi menarik perhatian para menner Belanda dan para juragan pribumi. Penindasan terhadap kaum perempuan yang tidak diberikan hak yang penuh karena perempuan dianggap sebagai makhluk yang 
lemah membuat mereka tertarik untuk mendapatkan kesejahteraan hidup secara instan. Penggunaan ilmu pelet merupakan salah satu jalan pintas yang paling ampuh untuk dapat mewujudkan keinginan tersebut, meskipun resiko yang harus ditanggung tidak main-main. Bagi mereka yang terpenting adalah kesejahteraan hidup yang menjanjikan menjadi hal yang paling utama, daripada mereka harus menahan siksa hidup yang keras. Jaran goyang merupakan salah satu ajian yang paling popular. Hingga saat ini keberadaannya masih sering terdengar di tengah masyarakat. Persyaratan dan mantra khusus yang diucapkan diyakini, mampu membuat target atau sasaran mudah terbius oleh rayuan si pengguna.

Supri banyak memberikan informasi di balik sisi gelap pembangunan jembatan ini. Salah satunya adalah keberadaan PSK yang sengaja ditimbun dalam tiang cor karena makhluk gaib yang menginginkan tumbal perempuan muda (Zidan \& Bonaventura, 2019: 30).

Kutipan di atas menceritakan bahwa para perempuan digunakan sebagai tumbal dalam pembangunan jembatan. Tanah Jawa selalu identik dengan hal-hal mistis. Banyak cerita yang mungkin sudah terdengar di telinga kita, dalam setiap pembangunan ada yang memerlukan tumbal atau sesajen. Salah satunya yaitu seperti pada kutipan di atas. Dalam kutipan tersebut disampaikan bahwa selain hanya dianggap sebagai pemuas nafsu, perlakuan Belanda terhadap perempuan yang kejam juga terlihat pada kutipan di atas. Dalam kutipan tersebut digambarkan bahwa perempuan Jawa juga dijadikan sebagai tumbal dalam pembangunan bangunan. Pemerintah Belanda tega mengorbankan perempuan Jawa yang dijadikan sebagai tumbal untuk makhlukmakhluk halus. Hal ini menjadikan perlakuan diskriminasi yang dilakukan oleh para penjajah kepada perempuan. Mereka yang tidak bersalah dan tidak tahu apapun harus menanggung beban.

\section{SIMPULAN}

Sastra menjadi bagian dari kisah sejarah kehidupan manusia. Meskipun perdebatan sering muncul karena adanya sifat fiksi atau rekaan, tetapi karya sastra selalu berusaha untuk menggambarkan kedaan masyarakat pada suatu masa. Melalui pengamatan yang dilakukan oleh pengarang, mampu menuliskannya ke dalam bentuk cerita yang dapat dijadikan sebagai pembelajaran kepada pembaca agar lebih baik ke depannya. Berdasarkan hasil penjabaran terkait fakta kemanusiaan yang telah dilakukan di atas, novel Kisah Tanah Jawa ini merepresentasikan kehidupan pribumi pada masa kolonial Belanda. Novel ini menceritakan penderitaan kehidupan pribumi yang disebabkan karena adanya diskriminasi atau penindasan yang dilakukan oleh bangsa Belanda. Beberapa bentuk gambaran kehidupan pribumi tersebut seperti perempuan yang dijadikan gundik atau pelancur dan dijadikan tumbal. Novel ini juga menggambarkan kehidupan masyarakat pribumi dipaksa untuk kerja rodi dalam sistem pekerjaan atau mata pencaharian yang dibuat oleh Belanda dan berdampak pada ekonomi pribumi, demi kepentingan pemerintahan Belanda pada waktu itu. Akibatnya kemiskinan meraja lela melanda kaum pribumi karena mereka dipaksa bekerja, tetapi gaji yang mereka dapat diminta lagi oleh Belanda (kerja paksa) sehingga masyarakat pribumi pun terpaksa mengadakan ritual seperti babi ngepet untuk menambah penghasilan atau mendapatkan kekayaan lebih. Novel ini juga menceritakan bentuk penindasan Belanda yang memandang derajat pribumi lebih rendah agar kekuasannya untuk menduduki tanah bumiputra tetap bertahan.

\section{DAFTAR PUSTAKA}

Abdullah, M. (2013). Konvergensi SantriAbangan. Surakarta: IAIN Publisher.

Amin, S. M. (2010). Sejarah Peradaban Islam. Jakarta: Amzah. 
Audriana, S. (2018). Representasi Realitas Sosial dalam Novel Tan Karya Hendri Teja/: PerspektifRealisme Sosialis Georg Lukacs Septian Audriana. Bapala, 5(1), $1-10$.

Basid, A., Nur, I. J., \& Zuhdy, H. (2018). Pola Kehidupan Masyarakat Pontianak dalam Novel Kau, Aku, dan Sepucuk Angpau Merah Karya Tere Liye Berdasarkan Perspektif Strukturalisme Genetik. Lingua, 14 (21), 97-111.

Daliman, A. (2012). Sejarah Indonesia Abad XIX-Awal Abad XX. Yogyakarta: Penerbit Ombak.

Djakariyah. (2014). Sejarah Indonesia II. Yogyakarta: Penerbit Ombak.

Endawarsana, S. (2012). Teori Pengkajian Sosiologi Sastra. Yogyakarta: UNY Press.

Faiz, F. (2019). Ngaji Filsafat 151/: R. A Kartini - Feminisme. Retrieved May 19, 2019, from https://www.youtube.com/ watch? $\mathrm{v}=\mathrm{MdPk} 28 \mathrm{cHxG} 4$

Hafid, A. (2017). Diskriminasi Bangsa Belanda Dalam Novel Salah Asuhan Karya Abdoel Moeis (Kajian Postkolonial). Kembara, 3(3), 123-134.

Kartodirjo, S. (2014). Pengantar Sejarah Indonesia Baru: 1500-1900. Yogyakarta: Penerbit Ombak.

Krismawati, Y. (2013). Falsafah "Nrimo" dalam Budaya Jawa Ditinjau dari Tugas Pendidikan Kristen Berdasarkan PerspektifPsikologis. Jurnal Teologi dan Pendidikan Agama Kristen, 1(1), 22 34.
Mahayana, M. S. (2014). Kitab Kritik Sastra. Jakarta: Pustaka Pelajar.

Mouton, \& Co, S. (2017). Sejarah Perempuan Inondesia. Terjemahan:Elvira Rosa, Pramita Ayuningtyas, dan Dwi Istianti. Depok: Komunitas Bambu.

Purwandono, A. (2019). Tim Kisah Tanah Jawa Berkisah/: Mahluk Tak Kasat Mata Juga Narsis. Retrieved September 19, 2019, from https://krjogja.com/web/ news/read/93509/Tim Kisah Tanah Jawa Berkisah Mahluk Tak Kasat Mata Juga Narsis

Ratna, N. K. (2013). Stilistika. Yogyakarta: Pustaka Pelajar.

Ricklefs, M. C. (2012). MengIslamkan Jawa. Terjemahan oleh FX Dono Sunardi \& Satrio Wahono. 2013. Jakarta: Anggota Ikapi.

Ridwan, I., Aries, W., \& Yulianeta. (2016). Pandangan Pramoedya Terhadap Resistansi Perempuan dalam Novel Era Revolusi dan Reformasi. Adabiyyat, 15(1), 63-84.

Saputra, J. I., \& Etmi, H. (2018). Jugun Ianfu dalam Dua Karya Novel Zaman Pendudukan Jepang (1942-1945). Jurnal Diakronika, Edisi Khus, 45-57.

Suaka, I. N. (2013). Analisis Sastra: Teori dan Aplikasi. Yogyakarta: Penerbit Ombak.

Wicaksono, A. (2016). Kearifan pada Lingkungan Hidup dalam Novel-Novel Karya Andrea Hirata (Tinjauan Strukturalisme Genetik ). Jentera, 5(1), 7-21. 
Yurnal (2016). Pembangunan Negara Hukum Berbasis Human Developlemt Index: Sebuah Renungan Philosophy. $A L$ MURSHALAH, 2(2), 1-7.

Zidan, M. (2019). Pengalaman Membaca Buku Kisah Tanah Jawa - YouTube. Retrieved May 26, 2019, from https:// w w w . y o u t u b e c o m/ watch? $\mathrm{v}=6 \mathrm{QPtQUsZkSk}$
Zidan, M., \& Bonaventura, D. G. (2019). Kisah Tanah Jawa. Jakarta: GagasMedia. 